\title{
It's not what you do, It's the way that you do it? Of Method and Madness
}

\author{
Rob Gray \\ School of Management, \\ University of St Andrews \\ Scotland \\ rhg1@st-andrews.ac.uk \\ Markus J. Milne \\ Department of Accounting and Information Systems \\ College of Business and Law \\ University of Canterbury \\ New Zealand \\ markus.milne@canterbury.ac.nz
}

DRAFT 2c: August 2014

\section{PLEASE QUOTE FREELY}

Acknowledgements: We are very pleased to acknowledge Dean Neu's help and support and the opportunity to take part in this series of commentaries. We are very grateful for the comments of Sue Gray, Alan Richardson, Janis Russell and Dana Wallace on previous versions of the paper. 


\title{
It's not what you do, it's the way that you do it? Of Method and Madness ${ }^{1}$
}

\begin{abstract}
This short essay takes the opportunity presented by the paper by Patten (this issue) ${ }^{2}$ to enter the debate concerning the relative pros and cons of quantitative versus qualitative research methods. Too often, this is a sterile 'debate' and in accounting especially, the actual lack of real debate is destructive - manifest as it is in the pernicious attachment of key academic journals to a single (and largely unexamined) notion of what comprises good research and consequently what is permitted as knowledge. This restriction has additional unanticipated consequences in that it (a) refuses to acknowledge research findings that appear in journals other than those anointed by the high priests of self-styled positivism and (b) it severely limits the research questions that can be addressed to only those which can be perceived and addressed through a narrow array of method (Chua, 1986). We argue that such a position is untenable as well as undesirable and, following Feyerabend and Morgan (as well as Caldwell, McCloskey and Tashakkori \& Teddlie), argue for pluralism in method choice grounded in a pragmatic philosophy driven firstly by a concern for the research problem, and an absence of a fact-value distinction. We suggest that such pluralism is especially important in an area concerned with social and environmental issues which, ultimately, are matters of life and death and more important than trivial matters of 'which method is best', (or perhaps - more accurately - which method is permitted in journal $X)$.
\end{abstract}

\footnotetext{
${ }^{1}$ The title is a loose attempt to echo the famous 1930s song "T'ain't What You Do (It's the Way That You Do (t)".

${ }^{2}$ It is appropriate to note at the outset that the paper to which we initially responded was a statistical retesting of the conclusions of Dhaliwal et al., (2012). That paper was to act as a straw man to which we might respond. Patten's initial straw man, however, turned into a snowman as it melted away to be replaced by the present (excellent) piece now appearing as Patten (this issue): thus requiring that many of our original comments and criticisms were revised, revisited and some removed. The loss of such specificity raised the risk that our comments would become either too general or less insightful and less acerbic. We have attempted to overcome this challenge but without assuming a wide reading of the more mindless, typically North American, main journal "empirical" publications parading as superior knowledge of corporate social responsibility accounting.
} 


\section{It's not what you do, it's the way that you do it? Of Method and Madness}

\section{Introduction}

“.... It appears increasingly clear that analytical sophistication and the playing of statistical games have become the overriding obsession of researchers in the area [of social and environmental accounting] and hence such studies, rooted as they are within the prevailing economic and political status quo, can be largely considered as exercises in irrelevance as far as advancing the SEAA agenda is concerned" (Owen, 2008b, p27)

It is a truism - almost facile in its obviousness - that evaluating anything requires some means by which to evaluate it, some criteria against which to assess it. Evaluating research and scholarship is notoriously difficult (see, for example, Black, 1993; Worthington and Hodgson, 2005) not just because of the impossibility of articulating a simple judgement on such a complex activity - let alone the impossibility of making any sensible measurement of the activity itself (Hofstede, 1981 ) - but, most obviously, because of the diverse range of criteria against which it might be judged, (see, for example, Humphrey and Lee, 2008; p1). But, of course, the criteria we choose are likely to depend, to a fair degree, upon the extent to which we address - and how we then answer - the broader question of 'what are we for?'. It is not just that such a question is largely what gives our scholarship meaning but also as we sit in our comfortable, molly-coddled and largely undeserved selfabsorption, we should not escape, we would argue, the notion that our privilege brings with it an equivalent level of responsibility. That responsibility is, it seems to us, to seek to address the most important of the problems that we perceive and which may fall within our purview and ability, (Sikka et al, 1995; Fogarty, 1998; Lee and Williams, 1999). And it is what we determine to be important that gives meaning and purpose to our research (see, for example, Jones et al, 2000) and, arguably, to our lives. These arguments hold especially strongly for social, environmental and sustainability accounting, (Owen, 2008a; 2008b).

The reason why such concerns are so crucial to research in social, environmental and sustainability accounting (SEA hereafter) - as, indeed they are in corporate social responsibility (CSR) and the whole sustainability and business "debate" more widely - is that the field can be (on the face of it at least) so profoundly trivial. It remains so superficially trivial unless one can place the theorising, the empirical work 
or the normative imagination around SEA into some broader social, environmental, political and/or moral context. Any research process that creates an artificial distinction between 'facts' and 'values' in such a context, we would argue, seems patently absurd, if not downright outrageous.

The triviality of SEA has been widely remarked upon (e.g. Spence et al, 2010). The practice of social, environmental and 'sustainability' disclosure is so patently spasmodic, partial, incomplete and selective; it so obviously tells everybody virtually nothing about the actual social, environmental and sustainability impacts of the organisation or even anything about its 'social and environmental performance' (whatever that is); and most profoundly it fails to discharge anything that might look like accountability. Indeed, it is not even obvious that investors (let alone investment analysts) take anything other than the most marginal of risk signals from it, (see, for example, Murray et al, 2006; Chan \& Milne, 1999; Campbell \& Slack, 2008, 2011). With a relatively few notable exceptions, SEA disclosure appears to only make any sense at all as a relatively minor element in the organisational arsenal of legitimation, corporate preening and narcissism, perhaps signalling ${ }^{3}$, stakeholder management, boundary management and so on. There is no immediate empirical reason why such SEA might commend itself to our attention more than do (say) the dietary habits of board members, changes in photographic techniques or the reading habits of speculators.

Equally, there seems little evidence that SEA in an internal management accounting context fares much better. Although within organisations SEA has slowly become more integrated with other mechanisms such as environmental management systems (see, for example, Schaltegger et al, 2008) it is not at all obvious that even environmental accounting is that widely practised. Equally, it is not at all obvious that environmental accounting is crucial to organisational functions, at least not beyond the broader concerns of risk management.

And yet there at least three senses in which SEA is anything but trivial.

First, the total volume of activity - however hollow it might be - thought of as SEA in annual report disclosure, in the construction of stand-alone reports, in the formulation of policies and institutions, in the phenomenon of assurance and related 'standards',

\footnotetext{
${ }^{3}$ But to whom and what remains distinctly vague.
} 
and in the sheer effort to avoid it substantively entering the legal requirements of organisational functions, is very far from insubstantial, (see, for example, Hoffman and Ehrenfeld, 2013). This alone commends itself to our attention as the world of practice quite transparently considers this apparent schizophrenia well worthy of its efforts and resources.

Secondly, whilst it would be very difficult to provide formal evidence of a conscious volition, (or perhaps even conspiracy), the steadfast refusal by business, accountants and politicians to engage with any notions of substantive accountability and/or sustainability accounting is genuinely arresting. Indeed, it goes further and there is clearly an absolute refusal to even consider the issues substantively. These refusals speak volumes to us if we have the ears to listen.

Thirdly and consequently, as Owen (2008b) so eloquently demonstrates, any SEA that was substantive and which avoided capture by capitalism and managerialism would be profoundly disruptive of current hegemonic narratives - those both within and without the academy. A substantive SEA would probably demonstrate that corporate claims for `social responsibility' and 'sustainability' were vacuous at best and pernicious and destructive lies at worst. It would probably show that no company of any size (at least in the Western world) had made a profit (however defined/measured) once social and environmental matters (i.e. negative externality costs) were factored in; it would probably expose the idea that large companies cannot be either responsible or sustainable (Bakan, 2005; Milne \& Gray, 2013). It would probably clarify that the profit of companies is, more often than not, a combination of the appropriation of the wealth (and lives) of others, a source of inherent inequality and a result of using (i.e. destroying) capital (environmental and social) and claiming it as income. In short, something akin to a giant Ponzi scheme. It would show, most clearly, that we live in a world of dishonesty, oppression and madness.

Now that gives- albeit potential - piquancy to this mostly (superficially) trivial activity. And it goes some way to suggesting some possible explanations for why the business and professional worlds would work so very hard to maintain this sense of triviality and mask the un-sustainable destruction taking place (see, for example, ICAEW, 2004; Willis, 2003; Fries et al, 2010; United Nations, 2002; WBCSD, 2000, 2002a, 2002b). 
There are many ways in which we might choose to articulate and frame the potential importance of SEA, but it is that importance which raises research in the field to a level that justifies academic privilege and freedom (Jones et al, 2000) - that, in effect, articulates research as a component of scholarship and as an important part of a project worthy of our attention. This is something that critical theorists have known all along (Lowe and Tinker, 1977; Tinker, 1984; Hammersley, 1995) and something that SEA, to varying degrees, has sought to embrace. Namely that it is the problematique that gives context to SEA (as any other) research and gives it (for example) moral, political and social value. Of course we may recognise the relative inability of such research to directly influence practice, the ambient political economy or mainstream thought. Of course we would recognise the immanent nonsense that results from the privileging of publication over scholarship. And this is not, of course, to suggest a totalising view of what constitutes an appropriate problematique or that every piece of work we do needs to be redolent with passion and revolution. But, we would maintain, it is the contribution to an appropriate problematique which provides the basis upon which evaluation of research (assuming, of course, that it is competently executed) should rest.

Now what follows from this argument is the arresting suggestion that the privileging of 'problem' over such things as publish-ability, citations, method, methodology, convenience or (what Wheen, 2004, p89 calls) the "tyranny of twaddle", leads us to judge our research questions and how we answer them by the contribution they make to 'the project'. This suggests that, actually, method is a very secondary concern. The point in social and environmental accounting research is that is what you do (i.e. the selected problem/issue focus) that matters. How you do it (assuming you do it well) is, at least, relatively unimportant and possibly even largely irrelevant. ${ }^{4}$

This is the essential contention we would like to explore further in this short essay. We have no intention of offering yet another re-evaluation of SEA, this has been

\footnotetext{
${ }^{4}$ We recognise immediately that to some of our colleagues, most typically from North America we suspect, this will sound like heresy. We discuss this relative emphasis on problem/method more fully throughout this essay. (However, the reader should note both authors come from a UK-based academic lineage). We suspect a significant influence on the North American approach to accounting research and a preference for modelling/quantitative methods lies in part in the structure of the North American PhD training of advanced courses (including methods) plus a thesis. This stands in contrast to the UK model, for example, of a 3-year thesis only approach in which methods are learned "on the job" and as appropriate to the problem being investigated. Indeed, in many UK-style PhD 'programmes', it is not unusual for a candidate to spend the first year finding "their problem" and defending a proposal.
} 
more than adequately summarised most recently by Correa and Laine (2013). No, what we wish to discuss, in the round, are the dangers of any argument that one, single, approach to research is necessarily best (i.e. superior and therefore necessary, required, or permitted) and we wish to explore the contention that a much more profligate, perhaps even promiscuous, approach to research design offers a much more fruitful approach to project development. This is especially true in SEA.

Consequently, this short essay seeks to revisit and rehearse these issues. The start (in Section 2) from the 'which method is best' literature is unfortunate but it seems as if some of the self-evident truths in this area may not be so self-evident. Section 3 is an attempt to synthesise a range of the issues that arise in what we see as 'bad postivism' - so much of which we believe comprises the hegemonic research agenda of the North American accounting academy. Section 4 returns to SEA and offers a brief plea for more interesting and important research - regardless of the method.

\section{Of Method and Madness}

... "The progress of science ....depends on an openness of world views which conflicts with the totalitarian pronouncements of many of [its] defenders. ...World views ...take a long time.... before they ...'command recognition' and what 'commands recognition' in one community, is often without interest and even damaging in another" (Feyerabend, 2011, p43)

"Whoever undertakes to set himself up as a judge in the field of Truth and Knowledge is shipwrecked by the laughter of the gods." (Einstein, 1954, p30). ${ }^{5}$

The question of the innate superiority of one method or of a family of methods, or of quantitative or qualitative methods, for example, continues to exercise a significant proportion of the accounting community - as elsewhere. For well over three decades (Abdel-khalik and Ajinkya, 1979; 1983; Tomkins and Groves, 1983; Chua, 1986; and, more recently, for example: Ahrens, 2008; Lukka, 2010; Modell, 2010; Lukka \& Modell, 2010; Broadbent, 2012) accounting has been beset by 'schools' to whom only one family of methods is acceptable (Baker, 2011) ${ }^{6}$. Such an attachment would, we might have thought, be self-evidently unsupportable as a point of view - but it is clearly not quite as self-evident as we might assume. Whilst preference for method probably owes a great deal more to psychology and predisposition than to anything

\footnotetext{
${ }^{5}$ The origin of this quote is somewhat vague. While it certainly was used by Einstein, it has been attributed to Edmund Burke and Francis Bacon.

${ }^{6}$ Feyerabend (2011) makes the arresting observation that "Most .... philosophies started as attempts to put an end to the battle of the schools. They did not succeed. The attempts soon became schools themselves and joined the battle" (p9). For further examples of debates over methodology see Laudan (1996), Denzin (2008); Caldwell (2003); McCloskey (1998), Tashakorri \& Teddlie (1998; 2010).
} 
vaguely 'rational' (see, for example, Morgan, 1983; Choudhury, 1987; Berry and Otley, 2008, p234), it is manifestly reified on a daily basis in the journals and what they do or do not accept as knowledge or research ${ }^{7}$. This, in turn, becomes selffulfilling as faculty strive for tenure in solipsistic schools and as neophyte accounting researchers are too often trained in a manner that leads to limited and self-referential attitudes to truth and knowledge (Lee, 1997; Schwartz et al, 2005; Baker, 2011, p211). So perhaps we do have to (albeit briefly) revisit the 'can any one method be best?' schism.

There is no need to rehearse in detail here the arguments $^{8}$ that might bring us within striking distance of Feyerabend's (typically mis-represented) "anything goes" conclusions (Feyerabend, 1975): This task is elegantly achieved by Gareth Morgan in a series of short pieces that conclude Morgan's edited collection (Morgan, 1983; see p368 et seq.). Morgan concludes that we should "understand that... conflict [between different paradigms] may be rooted in different conceptions of scientific enquiry and scientific knowledge and that no single set of scientific standards can claim monopoly over decisions as to what counts as valid knowledge" (p393). (See also Tashakorri \& Teddlie, 1998; 2010).

Morgan's synthesis can be briefly summarised around, what he calls, both ontological and epistemological uncertainties (p386) - a point so eloquently understood in Einstein's opening quotation. There is patently no way of independently determining whether there actually is an independent reality 'out there' which our science seeks to uncover, describe and analyse. Equally, there is no independent way in which to demonstrate that there is no independent reality 'out there'. In the end then it comes down to the privileging of criteria - the admissible predicates - by which one adjudges the theory or the knowledge: Thus 'scientific', 'valid', 'replicable', 'relevant', 'practical', 'falsifiable' and so on, join the realms of preference but which cannot themselves be justified in any independent or purely

\footnotetext{
${ }^{7}$ And, this is in all probability magnified by the proliferation of journal ranking lists (both academic and institutional) such as the Association of Business Schools, the Australian Business Deans list, the Financial Times 45, and an array of academic surveys of "which journal is best' (Milne, 2001; Hussain, 2013). Further still there is a rapidly increasing number of Schools worldwide that require publication as a KPI for all their staff and, regardless of focus, arithmetic or practicability tend to focus on the "high ranking" journals as the only measure of performance worthy of consideration. Inevitably, emerging scholars pick up on this and learn to focus all their attention in just this way. Very sad - and appallingly counter-productive, (Parker et al, 1998).

${ }^{8}$ Especially not in a journal like Critical Perspectives on Accounting where one can assume a relatively sophisticated level of methodological subtlety.
} 
rational manner - that is they are (as Quine, 1976; suggests) "admissible predicates" and are pre-rational - before the argument, in essence. All ontological belief is therefore always just that - a belief - and consequently any paradigm's truth-claims, the persuasiveness of its knowledge, depends on a community of belief, pretty much as Kuhn and Lakatos argued (Kuhn, 1962/2012; Lakatos, 1970). This produces the elegant and useful inference that all ontology is conditional or, as Quine prefers, 'tentative': "in science all is tentative, all admits of revision" (Quine, 1976; p245).

If all ontology must be tentative, uncertain and conditional, then it seems to follow, as Morgan shows, that all epistemology is equally tentative, uncertain and conditional: there are inevitable "limitations in our ways of knowing" (Morgan, p386). All knowledge is therefore, it would seem, conditional, tentative, (Laughlin, 1995) and it is through that embracing of doubt that our understandings will develop (Dewey, 1930). Such a set of inferences seems sound, largely irrefutable (under current hegemonies of reason anyway) and greatly liberating ${ }^{9}$.

There is, of course, a great deal more that can be said on this matter but this essential inference will be adequate for our purposes here: the absence of any independent foundational principle ensures that all knowledge must be conditional which, in turn, withdraws warranty from any totalising claims in knowledge production and encourages the embracing and exchange of doubt. It ushers in, what we would choose to see as, John Keats' epistemology of negative capability ${ }^{10}$.

One further point needs making before we try and develop the essay further. It is probably unfortunate that most debates around methodology start from a critique of conventional science and/or positivism, (typically associated with quantitative methods and sometimes also referred to as nomothetic methodologies). The failings of conventional science are then typically deployed as the principal justification for the development of and attachment to interpretive or ideographic methodologies, (typically associated with qualitative methods). Too often, it seems to us, this implies that ideographic methods are the solution to the nomothetic problem (see, for example, Gill and Johnson, 1997). Perhaps the most valuable contribution to be

\footnotetext{
${ }^{9}$ Although we are grateful to Alan Richardson for reminding us that, of course, this does not give warranty to all research however poor nor does it remove the necessity to consider each and every research problem very carefully indeed.

${ }^{10}$ This might be simply expressed as believing exclusively in $\mathrm{X}$ whilst accepting, without reservation, that not-X may be the case.
} 
drawn from both Morgan and Feyeraband (in their very different ways) is to realise that neither is a 'solution' nor 'answer' to the other; that all methods have grave limitations and no franchise on truth ${ }^{11}$; and that both should be explicitly selected by reference to the problem being addressed; how apposite the method is to the illumination of the issue (typically research design) and the admissible predicates which the researcher brings to the issue (see, for example, Tashakorri \& Teddlie, 1998, 2010, and in accounting, Modell, 2010). This liberates us to discuss, not 'which is the best method?' but which methods best suit my explicit intentions here? and how might the problem be better understood by a pluralism of research approaches?

\begin{abstract}
"Interpretative social science certainly offers a brand of insight that positivism cannot achieve, but on the other hand, positivism can also generate forms of knowledge that elude the interpretative approach" Morgan, (1983, p397)
\end{abstract}

The liberation that such an analysis brings is not just the recognition that the disenfranchising of forms of knowledge is a predominantly un-supportable activity but that it also has the effect of encouraging a much more thoughtful and inclusive approach to the questions that can and should be addressed: no longer are questions largely determined by the methods through which they might be answered, the data which is easily available and the 'normal science' by which they are framed and judged (Chua, 1986; Richardson, this issue).

Many areas of accounting already recognise this (see the earlier references to management accounting, for example) and one will find quantitative methods informing qualitative speculations - and, of course, vice versa. For instance the quantitative understandings of why investors buy certain shares have, rather more recently, been greatly enhanced by the use of qualitative methods and actually asking said investors (see, for example, Holland, 1998). Frequently (typically exploratory) fieldwork can expose suggestions to which quantitative methods can provide wider context or for which quantitative techniques may be used to explore the likely wider applicability of findings (one example might be gender and work

\footnotetext{
${ }^{11}$ Indeed, Morgan challenges qualitative researchers to develop means by which to introduce the same levels of scepticism in their methods as can be articulated in a thoughtfully applied positivism. (Morgan, 1982, p384)
} 
experience, and income levels). ${ }^{12}$ Often hypotheses developed using one set of methods can be so usefully explored using others (see, for example, Murray et al., 2006). Methods can so easily be used symbiotically to develop elements of problems $^{13}$.

We know that such a suggestion is frequently eschewed by both quantitative and qualitative researchers, but it is probably worthwhile to re-visit some of the key points underlying such a view ${ }^{14}$. Putting aside our anxieties for a moment there seems little question that regularities occur both in nature and, to a perhaps lesser degree, in human society. It is regularities which form the bedrock for the quantitative researcher - and we want to try and distinguish between, on the one hand, the search for and identification and analysis of regularities and, on the other, all the paraphernalia of functionalism, positivism and any claims to certainty/infallibility. The two are usefully distinct.

That is, quantitative methods are ideal for seeking out, identifying and exploring regularities in phenomena. Whether it be (for instance) rainfall and plant life; ambient temperature and species; chemical composition and flexibility or strength; we all find it useful to rely upon many of the regularities of natural science and engineering. In the social world such regularities can also be thought to exist. This is probably subject to rather more challenge than in the case of natural science including challenge over the processes and assumptions involved. Nevertheless: diet and height; parents' income and opportunity; humanity and environmental degradation; human-produced emissions and climate change; publication output and selfimportance; accounting training and tedium; are just some of the many examples with which society regularly engages and upon which we, to an extent at least, rely. And relying upon that only requires that we accept a sort of conditional ontology that whether through self-delusion or a belief - an article of faith - in a factual reality, our current understanding of human existence factors in and embraces the possibility of such regularities.

\footnotetext{
12 Bryman and Bell (2011) provide a particularly useful text on business research methods that embraces the notion of mixed methods research design and which avoids the rather restrictive positivist/quantitative, interpretivist/qualitative divide. See also Tashakorri \& Teddlie (1998, 2010).

${ }^{13}$ This is not to gainsay the dangers of incommensurability in evidence from different methods. Very broadly, we might suggest that triangulation of different evidences from different methods commends a more organic and tentative notion of "knowing" to us when evaluating states of nature.

${ }^{14}$ These points that may seem fairly self-evident but are, perhaps surprisingly, not widely accepted. Even the more determinedly qualitative research community often behave as if statistics are the work of the devil.
} 
Once this simple idea is accepted then we are in position to accept that the employment of both quantitative and qualitative methods in research can be an informative act but that the care with which the methods are applied and the critical reflection on the restrictions, assumptions and limitations remains essential. Indeed, as Latour effectively suggests with respect to natural science more widely (Latour, 2004), we must take these methods, their collated data and their associated processes most seriously - certainly more seriously that many positivists seem to take their 'science' (Patten, 2002) and, by extension, perhaps more seriously than many qualitative researchers take their problems.

"[Thus can we] emphasize the importance of critical reflection as a basis for action, to help researchers orient their activities in a way that attempts to take full view of the relations within which such action is set, the consequences of that action, and of alternative actions. Such a perspective would reorient the role of the researcher from that of a technical functionary pursuing a prespecified form of knowledge (as a foundational view of knowledge tends to encourage), and place responsibility for the conduct and consequences of research directly with the researcher. Each researcher would carry an obligation to reflect on the nature of his or her activity as a means of choosing an appropriate path of action" (Morgan p374).

Which brings us nicely to the issue at hand for this paper. Social (and environmental and sustainability) accounting, on the face of it at least, has long professed a concern with problem over method and consequently has been active in the embracing of research which employs all forms of methods (Patten, 2002). Although this self-regard may be unfounded (see, for example, Spence et al., 2010; Owen, $2008 b$ ), there is a principle here that the problem is what is (or should be) driving the enquiry. ${ }^{15}$

\section{Doing badly, that which shouldn't be done at all ${ }^{16}$}

The theories we construct, the hypotheses we test and the beliefs we have are all shaped by our systems of metrics. Social scientists often blithely use easily accessible numbers, like GDP, as a basis of their empirical models, without enquiring sufficiently into the limitations and biases in the metrics. Flawed or biased statistics can lead us to make incorrect inferences. (Stiglitz et al., Mismeasuring Our Lives, 2010, p.xix)

\footnotetext{
${ }^{15}$ This is, of course, entirely consistent with a pragmatic approach to research methodology, mixed methods design and pluralism. Which method(s) is selected depends on the problem at hand, and which is likely to deliver the outcomes that work, while understanding fully that what works is likely to be contingent and temporary. This problem choice/focus, call for constant experimentation, and abandonment of the fact-value distinction also provides the foundation to environmental pragmatism which eschews the theoretical and idealistic debate over the instrumental/intrinsic value of the environment in favour of working on concrete issues (see, for example, Norton 1996; Parker, 1996; Weston, 1985).

${ }^{16}$ This heading is a deliberate adaptation of the widely quoted critique "doing efficiently that which shouldn't be done at all" which is variously attributed to Tony Lowe, Peter Drucker, Kenneth Boulding and Paul Ehrlich.
} 
Our purpose here is not to provide a detailed critique of Patten's paper ${ }^{17}$ but rather to use the paper to prompt a number of comments about the role of quantitative methods in social and environmental accounting research; the myopic notion of what quantitative research becomes when it is determined by 4 or 5 solipsistic journals on a single continent and try to expose what is (in effect) 'bad positivism` (Patten, 2002). It probably advances all our causes if we can move beyond thoughtless dismissal of work for its failure to meet some arbitrary and precious criteria and start to concentrate rather on a more considered and explicit examination of how work fails to meet our carefully identified criteria $^{18}$ and, more importantly, how it fails to meet its own explicit (or more usually implicit) criteria. $^{19}$

It behoves us to recognise that whilst our own personal political orientations direct our preferences towards papers which exhibit concerns about: ecological desecration; social inequality; or the crass oppression of modern financial capitalism and its organs; few do so and that is not, necessarily, an intrinsic failing of quantitative research papers. The solipsistic journals demonstrate no concern at all for such global manifestations and consequently have nothing to say, in our judgement, on matters pertaining to the social accounting project. That is, if one wanted to know about social, environmental or sustainability issues the approach taken in the solipsistic journals would never cross your mind. This is not a rejection of quantitative methods but, rather, of the whole mindset typically conveyed in the 45 (mainly) US journals. Consequently, the solipsistic journals no longer speak to us: that is not a failure in and of itself. The failure within these journals lies in two major places. First, authors fail to justify (or even recognise that they need to justify) how and why they are able to ignore the substantial context of all current accounting (and the context that generates such absences of accounting). Secondly, as is very well known, these journals and their acolytes are intent upon imposing a totalising approach to research and knowledge which is entirely unjustifiable - and bizarrely still manages to hang on to the power to do so. ${ }^{20}$ It is not what is done that demands

\footnotetext{
${ }^{17}$ We outlined in footnote 2 how we ended up in this position regarding responding to Den's paper.

${ }^{18}$ Our selection of the privileging of problem and project may, equally, be a little precious but at least (we hope) we have made it explicit and our reasons for doing so.

${ }^{19}$ For more detail on "bad science" in accounting, see Murray Lindsay's work (see, for example, Lindsay 1995; 1997; Lindsay \& Ehrenberg, 1993; Hubbard \& Lindsay 2013a; 2013b).

${ }^{20}$ Why anybody still gives them warranty and doesn't just ignore them is largely a mystery to us, although we agree with the work of Tom Lee and Paul Williams who so eloquently illustrate how systems of academic power and elitism are maintained and reproduced.
} 
these responses it is that they are oppressive and come to dominate others to the point where they become the norm. That is outrageous.

These are points with which Patten (this issue) is in complete agreement. Consequently, in what follows we are not seeking to dismiss positivism or to say that any particular kind of work should not take place. (We might believe it politically but we cannot substantiate it intellectually). What we are trying to do is ask those whose gaze rarely stretches beyond the journals of solipsism, to try to recognise the glaring but understandable limitations of their work. In doing so they would thereby recognise that no method can be justified as 'superior' and, certainly, no method can be so dominating as to be legitimately totalising.

We would want to emphasise that we certainly do not want Den Patten to stop doing sums and start doing stories instead. ${ }^{21}$ The arguments Patten puts are substantial, the work he does is important and the world would be a worse place without it. One of the genuine potential elegances of positivist work is the harmony it can bring to the careful deduction of insightful hypotheses from a carefully constructed (and justifiable) thesis. Too often, it seems to us, neither the theory nor the deduction is treated as seriously as it needs to be and, therefore, relatively tedious hypotheses are plucked from the air supported by some fairly facile speculations. Such is the case in so much of the solipsist work in accounting and it is this we would like to briefly consider.

If we briefly imagine the stages in a (artificially linear) research process it might help us to throw into relief some of the buried assumptions that seem to be inevitable in research. Some of these buried assumptions are legion in the solipsist journals and some of which are even occasionally present in Patten (this issue).

Worldview: It seems a truism that one's worldview, political and spiritual allegiances, and levels of perspective, frame, determine and motivate one's work. One crucial contribution of the critical project (however we decide to define 'critical') has been to help scholars learn to expose the implicit contours of their worldviews. Rarely is this a completed project it seems: as we come to make explicit our assumptions and

\footnotetext{
${ }^{21}$ It is important to note that quantitative research is bound up in its own genre with a representative language, narrative and rhetoric - one needs a certain styled language to sell quantitative research as "scientific" (McCloskey, 1994; 1998) And this in part, at least, is why we suspect so much abject nonsense manages to break through the peer review process and become published - form it seems can trump substance.
} 
beliefs about power, goodness, the planet and the role of humanity, for example, so we can begin to understand differences (Tinker et al, 1991; Tinker and Gray, 2003) . Our contention would be that even Den's work exhibits a conservatism that probably would not embrace a deep ecology or see a world without financial markets, corporations, etc... as desideratum. But once this is articulated and made explicit we can debate the matter, acknowledge it as an underlying assumption and proceed in explicit recognition of it as a conditionality in our work. Indeed, we are reminded again that it is more often the character and motivation, training and awareness of the researcher which is really at issue - not rigour or method.

But training is crucial: a neophyte trained exclusively in a single literature and a single narrow method is, by definition, going to find it much harder to recognise that narrowness - framing is all. And consequently such a new scholar is so much less likely to be aware that other forms of scholarship are possible, let alone desirable. The trainers have much responsibility to bear here. Equally, having discovered and developed a particular capacity it is a relatively rare scholar who will abandon that focus and re-tool. ${ }^{22}$ It is not of pluralism per se that we speak, therefore, in the sense of individuals pursuing multiple research questions with multiple research methods, (although some might do so), but of the necessity of a wider recognition that this is (and should be) the wider purpose of the research community at large, and that calls for a wider perception, understanding and tolerance of all individuals' research preferences.

Purpose of Scholarship: It is in this spirit that Patten (this issue) is framed. A dominant motivation to seek to enlighten the unenlightened and to challenge hegemonic explanations and perceptions in the language of those very solipsists is highly admirable. To expose the internal absurdities of work is a very valuable act but the solipsist journals seem profoundly resistant to such enlightenment - as we can attest to personally (see also Tinker and Puxty, 1995) ${ }^{23}$ Patten's decision is a

\footnotetext{
${ }^{22}$ There are many who have done this, Jesse Dillard is one such character who has very successfully done this and who has a passing acquaintance with and affection for the social accounting project(s). There are other brave and admirable souls. Nonetheless, we are also aware of senior scholars (from various perspectives) who perceive their beliefs and methods as superior, and whose purpose is to convert and recruit acolytes to "outbreed" the "enemy".

${ }^{23}$ Ruth Hines tells of a similar story in her journey to publication in TAR. But the resistance doesn't just come in the form of having work from alternative perspectives rejected from the mainstream journals because it is seen as little better than "opinion" or a nice "after dinner talk". It also comes in having intolerant editors of
} 
political one that, broadly, reflects a reformist agenda to which we both subscribed for a substantial part of our careers - our view now being that a $40+$ year experiment to reform capitalism is long enough to reject the more optimistic of hypotheses. This does not invalidate a reformist motivation per se: rather it demands of us that such motivations are explored and exposed (Tinker et al, 1991).

It is these matters of politics, world views, training and so on which, to a degree at least, influence how a project is framed and established by the researcher.

This concern is not one of quantitative versus qualitative methods: outside the solipsistic journals there are many, many examples of work crossing the divide whilst embracing similar research motivations (as Patten, indeed, suggests). So our focus here is only partly on quantitative methods themselves and rather more on how such methods are understood (sic) and manifest in the solipsistic journals. After all, "science" is pretty crucial to most notions of sustainability: - the WWF reports, the GEO reports, the UN Millennium Declaration, Limits to Growth, and the IPCC reports are all scientific and positivist based analyses. Likewise, measures of inequality, disease, health statistics, poverty, etc...are all grounded in quantitative analyses - as Richardson (this issue) argues.

Framing of the Scholarship: At least part of this is recognising that different sorts of questions appeal to different sorts of minds and are best addressed through different sorts of methods. We have to say that we resent the notion that econometrics presumes to explain why we do (or do not) have children in our relationships and we would be intellectually underwhelmed by ethnographies of whether or not climate change and species extinction was taking place. But while we applaud papers such as Patten (this issue) joining prior work by (amongst many others) Cho and Patten (2013) and Coupland (2006) in explicit recognition of the need to challenge "mainstream accounting literature's myopic view" about CSR, there remains, too often, an implicit framing and theorising which comprises only corporations and their investors in a search for yet greater wealth. Indeed, we have never ceased to be both amazed and incensed that tax-payer funded scholars could spend so much of their time engaged in research which potentially benefits organisations and their investors already worth thousands of billions of dollars.

mainstream journals "overrule" critical and dissenting voices raising legitimate questions and concerns about the (critical) limitations to quantitative research papers during the review process. 
Whilst the solution is far from clear, there remains the distinct danger that challenging work within the paradigm, using all its own paraphernalia, merely helps reify the myopia of investors, financial markets and neo-liberalism. Yet to fail to engage solipsist econometricians in their own terms risks being marginalized by senior practitioners as "philosophic" or even metaphysical - something of a predinner appetizer before getting down to the real business of the "scientific" main course. And newcomers may simply not understand the nature of any challenge to such a view. Indeed, an anecdote illustrates this perfectly. Listening to a presentation, from an outstanding new scholar, of an exquisitely elegant analysis of how a western investor might enhance their wealth and the returns of their share portfolio by diversifying into emerging markets, one was struck by the thought that such talent could be deployed in analysing the negative wealth impacts on the emerging market and its society using precisely the same techniques -simply asking the question the other way around. No matter how the new scholar was addressed, they had no notion of what was meant, why it was interesting or why anybody might consider the problem. There is something structural in our education (most widely) that is constraining our discourse here.

Theory and Prior Literature: It should be obvious by now, that one of the problems that concern us here derives from a narrow range of accounting journals that are self-referential, exclusive and oddly powerful. Authors in these journals tend to ignore work in all other accounting journals and the evidence they offer. ${ }^{24}$ This is not only poor scholarship but bad manners as well. It is simply rude. This is especially bewildering in the field of SEA where the vast substance of research and scholarship in the field lies outside the solipsist journals - with the result that those journals have, as we have said, nothing to say to the social accounting project(s).

\footnotetext{
${ }^{24}$ This is, of course, an exaggeration, but it is not an outrageously great one. Anecdotally, one of us is reminded of a North American colleague who honestly admitted she only used four accounting journals for her work, and had not even heard of Accounting, Organizations \& Society. She is not an extreme example. One only needs to purview articles in so-called top accounting journals to understand their exclusivity. Moreover, as Milne (2001) documents, the inter-journal citation rates for The Accounting Review, the Journal of Accounting Research, the Journal of Accounting and Economics, and Accounting, Organization \& Society is outrageously high. Based on ten years of publications in those journals (1990-1999), Milne (2001) shows they cite each other $82 \%, 80 \%, 90 \%$ and $78 \%$ for US-based authors, and $87 \%, 81 \%, 78 \%$ and $75 \%$ for non-US-based authors respectively. A similar level of "deference" to the so-called "top-4" was observed for Contemporary Accounting Research at $75 \%$. Yet for the bulk of 22 other peer-reviewed accounting journals, citation rates to those four journals were lower: $60-70 \%$ for US-based authors and often less than $50 \%$ for non-US-based authors. One typically finds the greatest levels of "eclecticism" outside the four journals, and especially so if the authors reside outside North America. All of this, of course, is entirely consistent with Lee's and Williams' charge of elitism.
} 
Similarly, as Richardson (this issue) shows, this myopia results in a narrow range of theory being considered as either sources of hypotheses or as sources of explanation for phenomena. In essence, theory, such as it is, considers the pursuit by the rich and powerful of greater richness and power an apposite focus and one which is adequately articulated by a direct, functional almost robotic relationship between information and decision making. The dominance of information economics is simply astonishing, and testimony to the complete absence of imagination in a field so obviously filled with moral, political and social as well as economic complexity. One is led to speculate whether this is the best we can do for theory even assuming we think that investors' wealth is a matter worthy of our attention. Furthermore, we are led to wonder how (and if) that focus can be justified beyond a somewhat primitive neo-liberalism (Freidman, 1962; Jacobsen, 1991). We make these points because it seems to us that, as a community, we might make a better job of researching our world if we were required to more carefully examine our worldviews, their justifications and their compatibility with the meso-theory employed implicitly in our work.

Perhaps most importantly in this respect of theory, how do we move from patterns of association to claims about reasons and motivations and intentions without at least gathering some additional evidence? That is, the 'as if' (instrumentalist) justifications for agency theory and its analogues provide us with a disturbingly bankrupt picture of humanity and a very grey perspective on what is happening in the world. There is a habitual, it seems, drawing (assuming) of intentions/motivations without any additional augmenting evidence. Surely we can do better than that? Many of the studies on which such theorising and speculation rests were undertaken 20 or more years ago, and were perhaps novel at the time, yet we do need to encourage the solipsist journals to move on. Maybe this is Patten's project in brief.

Data: If there is one major issue that we believe neither Patten (this issue) nor Roberts and Wallace (this issue) address sufficiently it is the matter of data availability, or perhaps more correctly the unavailability of appropriate data, and what to do about it. Indeed we could question whether research questions and methods are driven only by the orthodoxy of the journals: it seems to us they are just as much a function of easily accessible data. Three immediate problems present themselves. First, as Richardson (this issue) notes, a raft of assumptions and preferences are 
built into these databases and that underlying basis is almost never explored. (The implausibility of the proxies that then result, we explore below). Secondly, and more potently, we would argue, many of the databases are generated by commercial and financial interest: only the factors that such interests are willing to pursue are manifest. Or, in other cases, databases were generated for purposes potentially quite at odds to which researchers put them, or in which researchers need to undertake quite unbelievable and utterly meaningless data gymnastics to force the data into a usable form. ${ }^{25}$

We would love to have a database of the ecological footprints of organisations or data on the ratio of highest to lowest paid employee or a database on the use of sweatshop labour in the supply chain or a database of levels of redundancies by organisation etc. These do not currently exist and so nobody wanting to get published in the solipsist journals in the North American accounting community can study them. The worst mistake a positivist can make, we believe, is to decide (or assume) that only questions for which data already exists can be worthy of study. ${ }^{26}$ The next worst mistake is to force available data intended for other purposes into a format for use for which it was never intended without so much as a by your leave. Thirdly, it is essential that we study absence; if we do not then the research agenda is largely set by companies, accountants, and financial markets. And of course, by its very reliance on regression based inter-firm analyses, the research is firm-centric. Virtually everything is quantitatively reduced to the level of the organization (and most particularly, that of the corporation).

Research Question: All of this brings us to an appreciation that the research question in the solipsist journals does not really stand a chance of being terribly interesting -

\footnotetext{
${ }^{25}$ A clear example here is the use of the US Toxic Release Inventory - a public data base with disaggregated chemical emissions data on specific chemicals at community and facility levels. Following the Love Canal disaster of the 1970s, its intent is to serve the "community's right to know" and provide local community members with details of imminent threats to their health from spills or discharges. Yet, such data is regularly "re-aggregated" across multiple facilities and multiple chemicals (often meaninglessly so we would argue from a scientific point of view) into global metrics for the unintended purposes of firm-level comparisons in econometric models. At no time is a scientific defence provided for such data manipulations, nor are the potential scientific limitations of such actions ever raised. We can only but imagine toxicologists falling about laughing at such potentially absurd behaviour, perhaps in the same way we would if they started adding loans to revenue or deducting depreciation from cash.

${ }^{26}$ Again, we wonder to what extent the expediency of available database driven research is contingent upon the "short-cycle" US-based PhD programme where perhaps as little as 12-18 months is available to complete the dissertation. This is perhaps then compounded by needs to publish in top journals and make tenure, where the new scholar publishes from their thesis, and then "learns" this is the way it works, further reinforcing the approach in their continuing career and the expectations they pass on to their own thesis students.
} 
or not interesting outside a really narrow understanding of normal science. This does not, in any sense, mean that those using quantitative methods cannot ask and answer interesting questions in interesting ways which advance the public interest, social accounting and/or critical understandings. Patten, Roberts and others are not alone in providing really outstanding insights. It is rather that if anybody obsessively focuses on reading and trying to get published in the solipsist journals, their questions must be neo-liberal, data-driven, corporation and investor focused and (as we see shortly) amenable to (to quote Roberts and Wallace, this issue) the latest econometric techniques. Consequently, almost by definition, no question that involves 'social responsibility', or 'social disclosure' or even 'sustainababble' (Engelman, 2013) is likely to have any substantial contribution to make to social responsibility, social disclosure or sustainability. The questions must, almost without exception, speak to investors' wealth, the cost of capital, risk to finance and so on. Who cares: when children are starving or dying of thirst? Or that the human population, ably abetted by corporate and investor greed, overshot the Earth's 2014 annual bio-capacity by the month of August.

So the solipsistic research question and the topic defined as 'interesting' must, by definition, be of almost no interest to most of humanity (except insofar as these activities are principal causes of the global problems) and thus of little or no interest to the social accounting project(s). Topic interest must, surely, at some level or other, be subject to some, however flexible, 'public interest' test?

Method and the Structure of the Research Question: It is not just the research question that must concern us here but the way in which the question itself is asked and, most especially, the whole issue of definitions, proxies and construct validity which are buried within the question. It is an area much under-examined in the whole field of SEA - not just the more positivistic work. This is a major factor (one we can only touch upon here) and another one to which, we would suggest, Patten (this issue) and Roberts and Wallace (this issue) give insufficient attention (at least for our preference). These comments may sound harsh, but if we are going to seriously debate the merit of quantitative methods, then data authenticity and data (construct) validity seem fundamentally crucial. To do otherwise is to risk being criticized for garbage-in-garbage-out. If there was one criticism that uniquely identifies 'bad' 
positivism it must be the flaccid construction of proxies; the unexamined assumptions of correspondence between concepts and constructs.

Perhaps the first plea is that terms like "CSR", "SEA", "environmental performance" and "social performance" and so on should all be (at a minimum) in quotations as they are both highly contestable (floating signifiers if you prefer) and they have attached meanings quite different to the implications of the way in which they are measured. They are often VERY bad proxies for things which often turn out to be tautologies (Gray, 2006). For example, some notion like the establishment of an "environmental management system" (EMA) is an important and interesting concept. Yet, it tells one nothing necessarily about an organization's interaction with the natural environment. Nor does it say anything necessarily about a firm's "environmental performance" (more on this below). Measured as a binary indicator (yes or no), EMS tells you whether a firm has (or claims to have) one or not: no more, no less. Socially constructed as a "variable" what does a measure of EMS tell you? What does it say about the firms' behaviours purporting to be "environmental management"? And what does it say about the researchers' constructions? There is no standardized definition of EMS; there is no standardized measure. And there is no necessary relationship between either the definition/concept, or the measure, or any 'real' actions or decisions the firm may be undertaking in its name. Quantitative researchers in SEA are not simply making observations of well-defined natural phenomena - as we typically assume do chemists and physicists. And neither are they engaged with well-established and standardized social phenomena like economic and accounting numbers. They are actively engaged in socially constructing highly ambiguous concepts and measures - too often, we believe, without careful and cautious deliberations. While it might sound harsh, 'plug and play' seems an apt description for much of what often passes. Too little effort we believe is spent on substantively establishing a great many so-called social and environmental metrics plugged into quantitative analyses. As Stiglitz et al (2010, p.xxv) so amusingly suggest:

"There is no single indicator that can capture something as complex as our society. Trying to capture what is going on by using a set of numbers that is too small can be grossly misleading. We might want to know how fast we are driving...and how far we can go before we run out of gasoline, but a single metric, say by adding the two numbers would tell us nothing about either question". 
Equally, for example, "quality" of reporting is a complex notion but it actually doesn't really need measuring in most cases of voluntary social and environmental disclosure. And this is because it is so clearly woeful by any of the standards that accounting would apply to its own variables. It is only obliquely approximated by a GRI proxy - itself a woeful approximation of anything related to accountability or sustainability (Buhr et al, 2014; Moneva et al. 2006; Milne and Gray, 2013).

So what should we make of notions like "corporate environmental performance", "social responsibility performance" or "sustainability performance"? These are terms frequently bandied around by quantitative SEA researchers, and indeed a great many other empirical researchers (Orlitzky et al., 2003; Clarkson et al., 2011; DixonFowler et al., 2013) but are they meaningful concepts and could they provide a basis for a variable that could be plausibly measured that stands for what it purports to be? Would such concepts and measures stand up in a court of law as admissible evidence? Would our colleagues in science fall about laughing at such constructions and measures as little short of fantasy? To William James (1909/1979, pp. 135136), we suspect, a great many are "vicious abstractions" - a process he believed to be one of "the great original sins of the rationalistic mind."

\footnotetext{
... We conceive a concrete situation by singling out some salient or important feature in it, ... then, instead of adding to its previous characters all the positive consequences which the new way of conceiving it may bring, we [reduce] the originally rich phenomenon to the naked suggestions of that name abstractly taken, treating it as a case of "nothing but" that concept, and acting as if all the other characters from out of which the concept is abstracted were expunged. Abstraction, functioning in this way, becomes a means of arrest far more than a means of advance in thought...
}

In a theatre actors perform actions to an audience, and seek to please or amuse. In sport, actors perform actions by competing against other actors, or against some defined standard of comparison (e.g. time). In these instances, the actors, the actions, and the cause and effect of the actions are relatively clearly defined and understood - one can attribute the actions to the actors as performance. In financial terms, we think of performance in terms of firm level actors (defined by legal or other (transaction) boundaries) and actions considered directly traceable or attributable to that entity, over a specified period of time, against benchmarks like breakeven, previous periods, future targets, or some other comparator, and for the purposes of inter-firm or inter-temporal comparisons, measured in standardized ways (i.e. ROA). 
Yet, as we know, measurement, and cause and effect knowledge of actions, and the cause and effect of those actions in financial terms, are far less clear.

With matters of a firm's social and environmental behaviours and effects, we suggest, it is several orders of magnitude murkier still. Is it even possible to "bound" a single corporation's social performance? How would one separate one corporations' environmental performance from another's? How would one separate it from other natural processes that affect the environment? Do SEA quantitative researchers even consider changes in the physical state of an organization's "natural" environment (even if we could agree on what bounds it) as part of that organization's environmental performance? It is when one starts to reflect on matters such as these that you realize that the social constructions by SEA researchers of concepts like "sustainability performance" are likely meaningless nonsense. Meaningless nonsense in the sense that they bear no necessary relationship to positive or negative changes in the physical (and/or social) environment that can be traced unambiguously to the actions of particular organizational actors over a given period of time, and against scientifically acceptable sets of rigorous measures or standards. Yet SEA researchers, for example, seem absurdly able to "proxy" firms' "sustainability performance" by membership or otherwise of the Dow Jones Sustainability (sic) Index.

We don't doubt events like the BP Horizon oil spill detrimentally screwed the physical (and social) environment of the Gulf of Mexico, and that some actions and effects will be attributable to BP as an organization - others might well be argued to be "preexisting factors" attributable to others, or to "natural" effects. In many other instances (for example, the responsibility for and the effects of non-point source pollution) it will be far less clear. What we seriously doubt, however, is that it is possible to meaningfully measure the effects of the BP spill in a way that permits them to be aggregated to the other effects of BP's actions elsewhere, and in a way that permits them to be sensibly compared to the actions and the social and environmental effects of other organizations in a simple comparative regression analysis. And, it is not as if this insight is new, or shouldn't have been taken on board by SEA researchers. Dierkes and Preston's (1977, p6, p14-15) seminal paper on corporate reporting for the physical environment couldn't be clearer: 
The nature and scope of environmental impacts varies so greatly among firms and types of economic activity that the search for a single set of analytical categories, measurement techniques, and decision-criteria for corporate social accounting reporting in this area seems almost certain to be fruitless.

They went on to state their proposed accounting framework:

...confines itself to reporting companies' commitments (inputs)....as well as performance data (outputs) which includes for example, the levels of pollutant emissions and changes in these levels. Secondary external effects - for example, the consequences of pollution on the health of the surrounding community or the general ecological system - are excluded. Such effects, although of great importance, can only be dealt with seriously in extensive and sharply focused studies which, due to the reasons previously mentioned, cannot be integrated into a continuous and regular reporting system.

The framework outlined here does not suggest the use of a unique performance measurement unit - and certainly not a monetary measurement unit - for all areas of environmental impact. On the contrary, it uses a wide variety of measures, appropriately developed for the various specific impact areas. This usage reflects the position stated earlier, that we see no way at present, nor for the foreseeable future, to define a common denominator integrating the diverse measurements that are available and appropriate for the various environmental impacts to be covered.... the integration of precise data into artificial indexes of "social welfare" or arbitrary monetary valuations hides, rather than provides, information, and thus serves as a barrier to understanding and decision making.

In other words, the physical environmental context of most organizations - and their interactions with it - are so complex as to be beyond simple reductive measures that might provide meaningful inter-firm comparisons.

In correspondence for this paper an interesting question arose: what should a quantitative researcher do if the only proxy is a poor one? If there is no "good" proxy for (say) CSR performance available right now, then should quantitative researchers not examine problems related to CSR performance at all yet? This is a big question which, sadly, is rarely considered and unfortunately is one we can only touch upon but there are several dimensions to it.

First, as we have said, CSR is at best a floating signifier and there is really no way that 'CSR performance' can be defined, let alone proxied, without some very careful definitional analysis. Second, there is an interesting implication that (often without realising it), a researcher may come to believe that they must have proxies. But we only need proxies (at least in this sense) if we are using quantitative methods, not otherwise. Third, and the most important of all, the implication seems to be that one must have proxies for which there is already conveniently available computerreadable data, and which must provide "comparable" inter-firm quantitative metrics. Invariably, then, rather than embrace the warnings of James (1907), Dierkes \& Preston (1977), and Stiglitz et al (2010), quantitative SEA researchers, to our way of 
thinking, too often fall back on existing simple, ill-fitting and inappropriate data sources, and excuse their use on the basis that they are a "proxy", or the only available proxy, and more often than not some other quantitative researcher has used them before. As if previous sloppy behavior justifies yet more sloppy behaviour.

The same behavior seems to justify the use of existing data sources with little critical probing and reflection. Take, for example, the KLD "environmental performance" ratings data - popularly used. Not only do these data sets confine themselves to the first order firm activities which Dierkes \& Preston (1977) indicate above, and so are essentially measures of "firm performance" (e.g., fines, emissions, etc..) rather than "environmental performance" (e.g. measures of physical environmental damage), the source of the data is the firm itself, not an independent party. In this context, then, researchers using KLD data to compare "environmental performance" with say "environmental disclosures" seem blissfully unaware they are largely comparing two socially constructed metrics of reported firm environmental behaviours from a single source - the firm. As a test of "authenticity" in the corporate reporting of firm level "environmental" behaviours to two audiences (i.e. KLD and the public) this is likely a valid argument. As a claim to be assessing "actual" environmental performance with "reported" environmental disclosure, it is clearly circular nonsense. Indeed, given the complexities to which Dierkes and Preston (1977) so eloquently allude, surely it is nonsense to believe anybody would know or could claim to assess without significant uncertainly what the "actual" environmental performance of any large firm could be. ${ }^{27}$ Indeed, all claims to know the actual environmental performance of an organization are just that, claims, more or less informed and almost certainly incomplete. One is reminded here of the fable of the 5 blind men and the elephant - all know it a little but none know what each know, and none know it all. Are we not simply reduced to making statistical comparisons of partial (and so meaningless) speculations? North American accounting-style quantitative methods for the solipsist journals, it seems to

\footnotetext{
${ }^{27}$ One only needs to reflect for the slightest moment on the sheer size and complex reach of many multinationals to understand that neither they nor anybody else can know the physical environmental effects of their behaviours let alone measure them. Perrow (1984) suggests many modern organizations and systems are so large and complex that one should expect "normal accidents" - a form of systemic failure from a lack of sufficient knowledge and inability to maintain control. In a similar way, with large modern organisations exceeding 250 billion dollars in assets and annual turnover - often in excess of many countries' economies, it is not hard to appreciate their operations have complex interactions with the physical environment that are beyond understanding and measurement.
} 
us, allows the "requirements" of the method to dictate how a question is structured, which in turn creates a voracious appetite for data - and any data, it seems, will do.

If one insists that only large sample econometrics are acceptable, then your questions are reduced to those that feature in a few journals, can be addressed using easily accessible computer readable databases and inevitably force you to employ bad (but easily accessible) proxies. Both the left and the right hand of your equations (as Richardson, this issue, argues) are reduced to very few variables indeed. It is in this context that Patten's arguments are at their most powerful but also (potentially) at their most limited.

Inevitably, conversations, training and evaluation focus more and more on the actual techniques and less and less on the thinking that goes into their application. We personally find this a little odd: when doing quantitative work we would consult a statistician or an econometrician; in the same way we consult philosophers when exploring philosophy, for example; and in the same way as if we wanted to publish in Portuguese we would consult a Portuguese speaker. We see our expertise as that of academic accountants, not econometricians or linguists. But the solipsist journals seem to be intent on arguing that only econometricians and statisticians can have anything to say about social life. That is patent nonsense. Herbert Simon (1960) calls it "mathematician's aphasia" - the over abstraction of problems so all semblance to reality is lost, and then the forgetting that the abstraction has taken place. Stephen Jay Gould (1996) raises other points about reification (mistaking the abstract for the reality it supposedly proxies). Having a proxy stand for something with which it may have only the very slightest relationship is one thing, but where things often go awry is that authors then draw conclusions as if the proxies were the thing they stand in for. Such research is therefore not adding to truth but actually misleading and obscuring any "truth". Gould's concern was the gross simplification of a complex and multi-dimensional phenomena such as human intelligence as a single measure of $I Q$ that could then be compared on a linear scale. For many researchers IQ became human intelligence, with all of its subsequent racial and other social policy prejudices that it entailed. 'Bad positivism' doesn't just lead to poorly thought out research publications.

Interpretation: Perhaps where this all falls down most profoundly is in the interpretation of the results. So little reflection is learnt, encouraged or exhibited in 
the solipsists journals so that the honest and modest reflection upon the profound limitations of the research (any research really) are lost and speculative and tentative conclusions are offered as facts. Too often the researcher's role here is left out. Once our students are taught to don the white coat, they are personally removed from the scholarship and only a few mavericks seem able to recognise this fact. Even then, engaging with this 'bad positivism' of others always runs the risk of contamination (as some parts of this conversation have shown) and perhaps even help in the social construction of these facts and the reification of the approach. How one deals with that is a more complex problem

But we cannot leave this hurried attempt to engage with the present paper without recognition of the central role of power and influence in what passes for the construction of knowledge in accounting (Tinker and Puxty, 1995). A great many colleagues who might choose to do more questioning work simply do not believe that they have the freedom to do so. They believe, with more than a little foundation that if they wish to keep their job (see, for example, Bebbington and Dillard, 2007) they have to do 'this stuff'. As Patten (2002) expresses it "To the positivist world I am too radical, but in the radical world I am too much the positivist. I am a boat person in the world of accounting research" (Patten, 2002; p8) and he makes a more general point not just about the climate in which many scholars work but the political choices one makes about where one believes change may be made more (or less) possible. The challenge Patten suggests is to attack the bad positivists and make common cause with the boat people of academic research.

\section{So what might we research and how might we do it?}

The sword of truth must be safeguarded within the sheath of goodness...In the modern world there is far too much emphasis on truth, on science, on physical facts, on measurement, and not enough on goodness, on compassion, on meaning and on wisdom. The balance needs to be restored. Satish Kumar (2014), Resurgence \& Ecologist, no 284, May/June, (p.1)

It is not difficult to find exciting and innovative work that takes a positive research slant on SEA. Modesty prevents us from identifying a number of such pieces but work such as Blacconiere and Patten (1994); Bouten et al (2012); Brown and Deegan (1998); Deegan and Rankin (1996); Neu et al (1998); Roberts (1992); all illustrate what can done with inventive and thoughtful quantitative exploration grounded on wider reading. So, in our view, the type of method chosen is simply not 
the issue: there are poor close readings, superficial ethnographies and bland descriptive case studies for that matter.

The issue is that the researcher should be asking an interesting question as part of an important problem informed by wider reading. Far too often this appears not to be the case with SEA (as with other) research. Mindless content analysis, predictable questionnaires and, generally, research into social, environmental or sustainability issues by researchers who patently know little or nothing about society, the natural environment or sustainability ${ }^{28}$, are not what humanity has need of just now.

Why would one undertake research into SEA? If the desire is simply to get a PhD and/or publish there are so many more fruitful areas that one could focus upon. If one wants to research SEA then the question has to be 'why? - what is the political, social, moral and/or policy motivation that is manifest in your study? Getting published in a 'top' journal simply doesn't cut it. SEA would be part of a more fruitful literature and generate wider and more substantive discussion if authors could, for example, explain why they want to enquire into matters such as whether some relatively vacuous social or environmental disclosure seems to influence investors.

Even with an investor or managerial point of view it could still be interesting to explore such matters as: the extent to which companies had tight, financial Friedman-style decision making; how different business cases were constructed; how and why corporations engage in apparent altruism and/or true philanthropy (see especially Campbell, 2007); why (as Bannerjee, 2007; for example raises) companies are so keen to portray themselves as socially responsible or sustainable; and how and why investors (social or otherwise) would be so stupid as to believe them; how far do/can environmental managers push the accounting conventions in investment appraisal?; and so on. There are many interesting and important questions to which, in all probability, imaginative and informed quantitative analysis can bring helpful insights and suggest new hypotheses.

A wider perspective offers unlimited possibilities where imaginative researchers whatever their preferred (or required) method allegiance - can continue to challenge

\footnotetext{
${ }^{28}$ An interesting question arises about how does a new researcher research anything when they know so little about it? How might an extant researcher redirect their efforts whilst not being an expert? The simple answers (and it is a complex question) would suggest that training should be in the subject matter and its content: techniques are much less important; and that secondly, as we have argued above, how can you justify your question as interesting if, indeed, you know nothing about it?
} 
perceptions and open new possibilities. Some suggestions include such matters as: why do stakeholders not penalise irresponsible behaviour (the case of British Petroleum (as was) continues to fascinate)?; how are 'the rules of the game' set/not set and consequently how might we define 'responsible behaviour'?; to what extent can ecological data be mapped onto organisations?; how has the marginal development of the law on social and environmental disclosure actually come about? Has it changed anything?; how are indices like Dow Jones Sustainability or FTSE 4 Good, actually constructed and why does anybody take them seriously? What do all those companies, institutions, professionals and, especially academics think they mean when they say `sustainability`?

What we do know is that such social and environmental disclosure as does take place does not discharge any wider accountability - or if it does it does so in only the very vaguest of terms and under the most trivial of assumptions. Similarly, we know that commercial organisations - and especially large and quoted commercial organisations have major social and environmental effects and that a priori their contribution to un-sustainability is compelling. Even good managerialist research could tell us more about this (see, for example, Young and Tilley, 2006) and if quantitative methods help us better engage with these issues, let us have more of that too. There is in fact considerable potential to what carefully crafted, well informed, positivist-based quantitative research design can meaningfully deliver to the social accounting project. The trick is, however, to keep one's primary focus on the research problem/issue, and not the methods (and attendant questions) permitted in the banal and facile publications of so-called 'top' journals.

We sit on a dying planet facing unprecedented levels of inequality and species extinction. There is a job needing doing and we, personally, don't much care how it gets done. As the mischievous misquote from the French revolution said of sociologists "give us the tools and we'll spend all day sharpening them". If that ever became true of SEA it would be an appalling indictment. As Howard Zinn (1997, pp. 499-507) in the Uses of Scholarship so acutely observes:

...the new urgency to use our heads for good purposes gets tangled in a cluster of beliefs...roughly expressed by the phrases "disinterested scholarship", "dispassionate learning", "objective study", "scientific method" - all adding up to the fear that using our intelligence to further our moral ends is somehow improper. And so we remain subservient to the beliefs of the profession although they violate our deepest feelings as human beings... 
Zinn's response is to point out many of these beliefs are simply myths and institutional routines that are both capable of challenge, and from which we can escape. Of course 'values' should determine the questions we ask, but not the answers we provide. We must learn to avoid the false dichotomy between fact and value, between the is and the ought, and overthrow the false belief that science is neutral and unbiased, and the scientist must remain disinterested, objective, and unemotional - the enemy being, according to Zinn, over specialisation and too narrow a reading. Zinn (1997, p.505) notes Rousseau's complaint that:

We have physicists, geometricians, chemists, astronomers, poets, musicians, and painters in plenty, but we have no longer a citizen among us.

In challenging the abdication of moral responsibility of the learned, Rousseau (Capaldi \& Lloyd, 2010, p.65) went on to suggest that:

\footnotetext{
...so long as power is alone on one side, and knowledge and understanding alone on the other, the learned will seldom make great objects their study, princes will still more rarely do great actions, and the peoples will continue to be, as they are, mean, corrupt, and miserable.
}

For us, it really does matter what you do, but how you do it (assuming you it do it well) seems much less important. To favour method over problem selection at this stage in the history of humanity (and those remaining species that still have a history) is patently absurd, morally outrageous (especially so for scholars of SEA, but for that matter any servant of the public purse), and clearly a form of madness. 


\section{Of Method and Madness: Quantitative Methods in Social Accounting}

\section{REFERENCES}

Abdel-khalik A.R. \& B.B.Ajinkya (1979) Empirical Research in Accounting: A Methodological View-point Accounting Education Series Volume 4 (Sarasota, Fl: Amercian Accounting Association)

Abdel-khalik A.R. \& B.B.Ajinkya (1983) "An evaluation of 'The everyday accountant and researching his reality'" Accounting Organizations and Society 8(4) (pp375-384)

Ahrens, T. (2008). Overcoming the subjective-objective divide in interpretive management accounting research. Accounting, Organizations and Society, 33(2), 292-297.

Bakan, J. (2005). The corporation: The pathological pursuit of profit and power. (Vancouver: Simon and Schuster).

Baker R. (2011) "A genealogical history of positivist and critical accounting research" Accounting History 16(2) May (pp207-221)

Banerjee S.B. (2007) Corporate social responsibility: The good, the bad and the ugly (Cheltenham: Edward Elgar)

Bebbington J. and J. Dillard (2007) "What really counts" Accounting Forum Vol.31 2007 (pp99-105)

Berry A.J. and D. T. Otley (2008) "Case-Based Research in Accounting" Chapter 14 in Humphrey C. and B. Lee (2008) The Real Life Guide to Accounting Research (London: Elsevier/CIMA) pp231-256

Blacconiere W.G. and D. M. Patten (1994) "Environmental disclosures, regulatory costs and changes in firm value" Journal of Accounting and Economics 18(3) pp357-377

Black T. R. (1993) Evaluating Social Science Research (London: Sage)

Bouten L., P. Everaert and R.W. Roberts (2012) "How a Two-Step Approach Discloses Different Determinants of Voluntary Social and Environmental Reporting" Journal of Business Finance \& Accounting, June/July 39(5) \& (6), (pp567-605)

Broadbent J. (2012) "Commentary on Parker: Groundhog day and optimism" Critical Perspectives on Accounting 23(1) pp71-77

Brown N. \& C.Deegan (1998) "The public disclosure of environmental performance information - A dual test of media agenda setting theory and legitimacy theory" Accounting and Business Research 29.1 Winter (pp21-42)

Bryman, A., \& Bell, E. (2011). Business Research Methods 3e. (Oxford: Oxford university press).

Buhr N., R. Gray and M. Milne (2014) “Histories, Rationales, Voluntary Standards and Future Prospects or Sustainability Reporting: CSR, GRI, IIRC and Beyond" Chapter 4 in Sustainability Accounting and Accountability (Eds) J. Bebbington J. Unerman, and B. O’Dwyer, (London: Routledge) pp51-71

Caldwell, B. (2003). Beyond positivism. (London: Routledge).

Campbell, D. and Slack, R (2008) Narrative reporting: analysts' perceptions of its value and relevance. Project Report. (London: Association of Chartered Certified Accountants).

Campbell, D., \& Slack, R. (2011). Environmental disclosure and environmental risk: Sceptical attitudes of UK sell-side bank analysts. The British Accounting Review, 43(1), 54-64.

Campbell J. L. (2007) "Why would corporations behave on socially responsible ways? An institutional theory of corporate social responsibility" Academy of Management Review 32(3) pp946-967 


\section{Of Method and Madness: Quantitative Methods in Social Accounting}

Capaldi, N., \& Lloyd, G. (Eds.). (2010). The Two narratives of political economy. John Wiley \& Sons.

Chan, C. C., \& Milne, M. J. (1999). Investor reactions to corporate environmental saints and sinners: an experimental analysis. Accounting and business research, 29(4), 265-279.

Cho, C. H. and Patten, D. M. The role of environmental disclosures as tools of legitimacy: a research note. Accounting, Organizations and Society, 2007, 32(7/8): 639-647.

Choudhury N. (1987) "Starting out in management accounting research" Accounting and Business Research 17(67) pp205-220

Chua, W. F. (1986). Radical developments in accounting thought. The Accounting Review, LXI: 4: 601-632.

Clarkson P. M., Y. Lic , G. D. Richardson, F. P. Vasvarid (2011) “Does it really pay to be green? Determinants and consequences of proactive environmental strategies" Journal of Accounting and Public Policy, 30 (pp122-144)

Correa C., and M. Laine (2013) Struggling against like-minded conformity in order to enliven SEAR: A call for passion" Social and Environmental Accountability Journal 33(3) (pp134-144)

Coupland, C. (2006) "Corporate social and environmental responsibility in web-based reports: Currency in the banking sector?" Critical Perspectives on Accounting, 17: 865-881.

Deegan C. and M.Rankin (1996) "Do Australian companies report environmental news objectively? - An analysis of environmental disclosures by firms prosecuted successfully the Environmental Protection Authority" Accounting Auditing and Accountability Journal 9(2) (pp50-67)

Denzin, N. K. (2008). The new paradigm dialogs and qualitative inquiry. International Journal of Qualitative Studies in Education, 21(4), 315-325.

Dewey, J. (1930). The Quest for Certainty: A Study of the Relation of Knowledge and Action: Gifford Lectures 1929. George Allen \& Unwin Limited.

Dhaliwal, D. S., Radhakrishnan, S., Tsang, A., and Yang, Y. G. (2012). Nonfinancial disclosure and analyst forecast accuracy: international evidence on corporate social responsibility disclosure. The Accounting Review, 2012, 87(3): 723-759.

Dierkes M. \& L.E.Preston (1977) "Corporate Social Accounting and Reporting for the Physical Environment: A critical review and implementation proposal" Accounting, Organizations and Society 2(1) (pp3-22)

Dixon-Fowler H. R., D. J. Slater, J L. Johnson, A. E. Ellstrand and A. M. Romi (2013) "Beyond "Does it Pay to be Green": A meta-analysis of moderators in the CEP-CFP relationship" Journal of Business Ethics, 112 (pp353366)

Engelman R. (2013) "Beyond Sustainababble" Chapter 1 in Assadourain E and T. Prough (Eds) State of the World 2013: Is Sustainability still possible?" Washington: Island Press) pp3-18

Einstein, A. (1954). Ideas and Opinions (New York: The Modern Library)

Feyerabend P (1975) Against Method (London: New Left Books)

Feyerabend P. (2011) The tyranny of science (Cambridge: Polity)

Fogarty T.J. (1998) "The stratification of academic accounting in the USA: A theoretical and empirical evaluation of institutional reproduction" Accounting Education 7(1) (pp3-20)

Friedman M. (1962) Capitalism and Freedom (Chicago: University of Chicago) 


\section{Of Method and Madness: Quantitative Methods in Social Accounting}

Fries J., K. McCulloch and W, Webster (2010) "The Prince's Accounting for Sustainability Project: creating $21^{\text {st }}$ Century decision-making and reporting systems to respond to $21^{\text {st }}$ century challenges and opportunities" in Hopwood A., J. Unerman and J. Fries (2010) Accounting for sustainability: Practical Insights (London: Earthscan) pp29-45

Gill, J \& Johnson, P (1997) Research Methods for Managers 2nd edition, (London: Paul Chapman Publishing Ltd)

Gould, S. J. (1996). The mismeasure of man. WW Norton \& Company.

Gray R.H. (2006) “Does sustainability reporting improve corporate behaviour? Wrong question? Right time?” Accounting and Business Research (International Policy Forum) 2006 Vol.36 (pp65-88)

Hammersley M (1995) The politics of social research (London: Sage)

Hoffman A.J. and J. R. Ehrenfeld (2013) Flourishing: A Frank Conversation About Sustainability (Greenleaf + Stanford University Press)

Hofstede G (1981) "Management control of public and not-for-profit activities" Accounting Organizations and Society 6(3) pp193-216

Holland J. (1998) "Private corporate disclosure, financial intermediaries and market efficiency" Journal of Business Finance and Accounting 25(1/2) Jan/March (pp29-68)

Hubbard, R., \& Lindsay, R. M. (2013a). From significant difference to significant sameness: Proposing a paradigm shift in business research. Journal of Business Research, 66(9), 1377-1388.

Hubbard, R., \& Lindsay, R. M. (2013b). The significant difference paradigm promotes bad science. Journal of Business Research, 66(9), 1393-1397.

Humphrey C. and B. Lee (2008) The Real Life Guide to Accounting Research (London: Elsevier/CIMA)

Hussain, S. (2013). Journal list fetishism and the 'sign of 4 'in the ABS guide: A question of trust?. Organization, 1350508413506763.

Institute of Chartered Accountants in England and Wales (2004) Sustainability: the role of accountants (in the Information for Better Markets series) (London: ICAEW

Jacobsen R. (1991) "Economic efficiency and the quality of life" Journal of Business Ethics 10. (pp201-209)

James, W. (1979/1909). The meaning of truth (Vol. 2). (Harvard University Press).

Jones G., K. Galvin and D. Woodhouse (2000) Universities as critic and conscience of society:The role of academic freedom New Zealand Universities Academic Audit Unit, March, AAU Series on Quality: Number 6 ISSN: $1174-8826$

Kuhn, T. S. (2012). The structure of scientific revolutions. University of Chicago press.

Lakatos I. (1970) "Falsification and the methodology of scientific research programmes" in I. Lakatos and A. Musgrave (eds) Criticism and the Growth of Knowledge (Cambridge: Cambridge University Press) pp91-195

Latour B (2004) "Why Has Critique Run out of Steam? From Matters of Fact to Matters of Concern" Critical Inquiry 30, Winter (pp225-248)

Laudan, L. (1996). Beyond positivism and relativism: Theory, method, and evidence. (Boulder: Westview Press).

Laughlin R.C. (1995) "Methodological themes: Empirical research in accounting: Alternative approaches and a case for 'middle-range' thinking" Accounting, Auditing and Accountability Journal 8(1) pp63-87 


\section{Of Method and Madness: Quantitative Methods in Social Accounting}

Lee T.A. (1997) "The editorial gatekeepers of the accounting academy" Accounting Auditing and Accountability Journal 10(1) (pp11-30)

Lee T.A. and P. Williams (1999) "Accounting from the inside: legitimizing the accounting academic elite", Critical Perspectives on Accounting, 10(6) December (pp 867-895)

Lowe A.E. \& A.M.Tinker (1977) "Siting the accounting problematic: towards an intellectual emancipation of accounting" Journal of Business Finance and Accounting Vol.4 No.3 (pp263-277)

Lindsay, R. M. (1995). Reconsidering the status of tests of significance: An alternative criterion of adequacy. Accounting, Organizations and Society, 20(1), 35-53.

Lindsay, R. M. (1997). Lies, damned lies and more statistics: the neglected issue of multiplicity in accounting research. Accounting and Business Research, 27(3), 243-258.

Lindsay, R. M., \& Ehrenberg, A. S. (1993). The design of replicated studies. The American Statistician, 47(3), 217-228.

Lukka, K. (2010). The roles and effects of paradigms in accounting research. Management Accounting Research, 21(2), 110-115.

Lukka, K., \& Modell, S. (2010). Validation in interpretive management accounting research. Accounting, Organizations and Society, 35(4), 462-477.

McCloskey, D. N. (1994). Knowledge and persuasion in economics. (Cambridge: Cambridge University Press).

McCloskey, D. N. (1998). The rhetoric of economics. (Madison: Univ of Wisconsin Press).

Milne, M. J. (2001). Debating accounting research journal rankings: empirical issues from a citation-based analysis and theoretical dilemmas from economics. Accountancy and Business Law Working Papers, University of Otago, New Zealand.

Milne M. and R. Gray (2013) "W(h)ither Ecology? The Triple Bottom Line, the Global Reporting Initiative, and Corporate Sustainability Reporting" Journal of Business Ethics 118(1) November (pp13-29)

Modell, S. (2010). Bridging the paradigm divide in management accounting research: The role of mixed methods approaches. Management Accounting Research, 21(2), 124-129.

Moneva, J. M., P. Archel and C. Correa (2006) "GRI and the camouflaging of corporate unsustainability" Accounting Forum 30(2) June (pp121-137)

Morgan G. (1983) (ed) Beyond Method: Strategies for social research (Beverly Hills: Sage)

Murray A., D.Sinclair, D.Power and R.Gray (2006) "Do financial markets care about social and environmental disclosure? Further evidence and exploration from the UK" Accounting, Auditing and Accountability Journal 19(2) (pp228-255)

Neu D., H.Warsame, and K.Pedwell (1998) "Managing public impressions: Environmental disclosures in annual reports" Accounting Organizations and Society 23(3) April (pp265-282)

Norton, B. G. (1996). Integration or reduction. Two approaches to environmental values. In A. Light \& E. Katz (Eds.), Environmental Pragmatism (pp. 105-138). London: Routledge.

Orlitsky M, F.L.Schmidt and S.L.Rynes (2003) "Corporate social and financial performance: A meta analysis" Organization Studies 24(3) (pp403-441) 


\section{Of Method and Madness: Quantitative Methods in Social Accounting}

Owen D.L. (2008a) "Adventures in Social and Environmental Accounting and Auditing Research: A Personal Reflection" in Humphrey C. and B. Lee (2008) The Real Life Guide to Accounting Research (London: Elsevier/CIMA) pp23-36

Owen D. (2008b) "Chronicles of wasted time? A personal reflection on the current state of, and future prospects for, social and environmental accounting research" Accounting, Auditing and Accountability Journal 21(2) pp240-267

Parker, K. (1996). Pragmatism and environmental thought. In A. Light \& E. Katz (Eds.), Environmental Pragmatism (pp. 21-37). London: Routledge.

Parker Lee, James Guthrie and Rob Gray (1998) "Accounting and management research: passwords from the gatekeepers" Accounting, Auditing and Accountability Journal 11(4) (pp371-402)

Patten D. (2002) "The Confessions of a Positivist (Radical) in a Radical (Positivist) World" Social and Environmental Accounting Journal 22(1) pp8-11

Patten D. (this issue) “An Insider's Reflection on Quantitative Research in the Social and Environmental Disclosure Domain" Critical Perspectives on Accounting

Perrow C. (1984). Normal accidents: Living with high-risk technologies. NY: Basic Books.

Quine W. V. O. (1976) The ways of paradox and other essays (Harvard: Harvard University Press)

Richardson A. J. (this issue) "Quantitative Research and the Critical Accounting Project" Critical Perspectives on Accounting

Roberts R.W. (1992) "Determinants of corporate social responsibility disclosure" Accounting, Organizations and Society 17(6) (pp595-612)

Roberts R.W. and D. M. Wallace (this issue) "Sustaining Diversity in Social and Environmental Accounting Research" Critical Perspectives on Accounting

Schaltegger, S., Bennett, M., Burritt, R., and C. Jasch (2008) (Eds.) Environmental Management Accounting for Cleaner Production (Dordrecht: Springer).

Schwartz, B. N., Williams, S., \& Williams, P. F. (2005). US doctoral students' familiarity with accounting journals: insights into the structure of the US academy. Critical Perspectives on Accounting, 16(3), 327-348.

Sikka P., H.Willmott and T.Puxty (1995) "The mountains are still there: accounting academics and the bearings of intellectuals" Accounting, Auditing and Accountability Journal 8(3) (pp113-140).

Simon, H. A. (1960). The new science of management decision. Englewood Cliffs, NJ: Prentice Hall.

Spence C, J, Husillos and C. Correa-Ruiz (2010) "Cargo cult science and the death of politics: A critical review of social and environmental accounting research" Critical Perspectives on Accounting 21(1) (pp76-89)

Stiglitz, J. E., Sen, A., \& Fitoussi, J. P. (2010). Mismeasuring our lives: Why GDP doesn't add up. The New Press.

Tashakkori, A., \& Teddlie, C. (1998). Mixed methodology: Combining qualitative and quantitative approaches (Vol. 46). Sage.

Tashakkori, A., \& Teddlie, C. (Eds.). (2010). Sage handbook of mixed methods in social \& behavioral research. (London: Sage).

Tinker A.M. (1984) (ed) Social accounting for corporations (Manchester: MUP)

Tinker T., Lehman C., and M.Neimark (1991) “Corporate social reporting: Falling down the hole in the middle 


\section{Of Method and Madness: Quantitative Methods in Social Accounting}

of the road" Accounting, Auditing and Accountability Journal 4(2) (pp28-54)

Tinker T. \& T.Puxty (1995) Policing Accounting Knowledge (London: Paul Chapman)

Tomkins C. and R. Groves (1983) "The everyday accountant and researching his reality" Accounting Organizations and Society 8(4) pp361-374 and "Further Thoughts" (pp407-415)

United Nations (NGLS/UNRISD ) (2002) Voluntary Approaches To Corporate Responsibility: Readings and a Resource Guide (Geneva: United Nations Non-Governmental Liaison Service)

Weston, A. (1985). Beyond intrinsic value: pragmatism in environmental ethics. Environmental Ethics, 7(Winter), 321-339.

Wheen Francis (2004) How Mumbo Jumbo Conquered the World: A short history of modern delusions (London: Fourth Estate) p89

Willis A., (2003) "The Role of the Global Reporting Initiative's Sustainability Reporting Guidelines in the Social Screening of Investments" Journal of Business Ethics 43(3) pp233-237

World Business Council for Sustainable Development (WBCSD) (2000), "Corporate social responsibility: making good business sense", WBCSD, January, available at: www.wbcsd.org

World Business Council for Sustainable Development (WBCSD) (2002a), "The business case for sustainable development", February, available at: www.wbcsd.org

World Business Council for Sustainable Development (WBCSD) (2002b), "Sustainable development reporting: striking the balance", WBCSD, December, available at: www. wbcsd.org

Worthington F. and J. Hodgson (2005) "Academic labour and the politics of quality in higher education: a critical evaluation of the conditions of possibility of resistance" Critical Quarterly 47(1/2) pp97-110

Young W. and F. Tilley (2006) "Can business move beyond efficiency? The shift toward effectiveness and equity in the corporate sustainability debate" Business Strategy and the Environment 15. (pp402-415)

Zinn, H. (1997). The Zinn reader: Writings on disobedience and democracy. Seven Stories Press. 